\section{Blood donors to be screened}

\section{Tokyo}

THIS week, Japan's Red Cross is expected to start screening all blood donors in Japan for hepatitis non-A non-B viruses using an antibody test kit developed by the US company Chiron. This will be the first nationwide programme in the world for screening this type of hepatitis virus and will give Chiron a commanding lead over other companies in Japan, where hepatitis non-A non-B is a major cause of liver disease and cancer.

Between two and four million people in Japan are believed to be carriers of hepatitis non-A non-B viruses. Every year, about 200,000 people, $10-15$ per cent of blood transfusion recipients, are infected with these viruses. They cause 60 per cent of Japanese cases of hepatitis (about 720,000 people) and 40 per cent of cases of cirrhosis of the liver $(100,000)$ and liver cancer $(7,000)$. The viruses cause 16,000 deaths a year in Japan, according to statistics for 1988 from the Ministry of Health and Welfare. But the viral agents responsible, of which there are several, both blood-borne and orally transmitted, have not yet been fully identified.

Last year, Chiron partially isolated and characterized a blood-borne viral agent that is thought to be one of the major causes of hepatitis non-A non-B. And last January the company provided the Japanese Red Cross with 10,000 samples of an ELISA (enzyme-linked immunosorbent assay) test kit developed in collaboration with Ortho Diagnostic Systems of the United States for trial screening.

According to results reported at an international symposium in Tokyo in September, the test kit detected antibodies in about 75 per cent of post-transfusion acute non-A non-B hepatitis patients. And the Red Cross has decided to begin immediate nationwide screening using 800,000 test kits imported through Ortho Diagnostics Systems' subsidiary in Japan.

The kits are being provided free of charge because the US subsidiary has yet to receive marketing approval from the Ministry of Health and Welfare. But approval is expected shortly and the free samples are a good marketing strategy, according to Mitsuru Miyata, editor of the newsletter Nikkei Biotechnology.

Two Japanese research groups backed by industry are in hot pursuit of Chiron. A group led by Professor Terukatsu Arima of Kagoshima University (formerly of Okayama University) which has links with Tonen (formerly called Toa Nenryo Kogyo), an oil refiner, has isolated clones that react positively with $60-70$ per cent of serum samples of patients of transfusionassociated chronic hepatitis non-A non-B. And Toshio Shikata of Nihon University, who is collaborating with the Chemo-Sero
Therapeutic Research Institute (Kaketsuken) in Kyushu, has also isolated one clone.

Both research groups have applied for patients for test kits and emphasize the difference between their results and Chiron's. But the limited data released so far suggest more similarity than difference with the US company's results, according to one expert observer of the competition.

The market for blood-screening kits in Japan is potentially enormous because Japan has about 8 million blood donors a year. But the Red Cross, which monopolat considerable discount and sales are expected to amount to only several million dollars as with AIDS screening kits.

At the same time, Japan's bloodcollection centres are not so familiar with ELISA antibody test kits of the type developed by Chiron and Ortho Diagnostic Systems. So Ortho Diagnostic Systems, in collaboration with Fuji Rebio, is developing a test kit based on Fuji Rebio's aggregation method, which is used for screening AIDS and adult T-cell leukaemia (ATL) viruses in blood donors in Japan. If all goes well, the kit could be on sale in Japan in the second half of 1990.

The market for kits to diagnose patients is slightly larger than that for blood screening and is expected to amount to about $¥ 1,000$ million ( $\$ 7$ million) a year, as in the case of hepatitis-B virus. But, in tests in hospitals around Japan, Chiron's ELISA kit showed positive results with only about 35 per cent of patients with sporadic non-A non-B hepatitis. The comparatively low percentage of positive results compared with post-transfusion patients is a mystery and has given Chiron's competitors hope that they can develop alternative tests.

But by far the biggest market lies in the development of a vaccine. Chiron has set up a joint venture with Ciba Geigy, called Biocine, for this purpose, and is keeping a tight lid on all information concerning the approximately 30 per cent of its cloned DNA (the part coding for structural proteins) that can be used for vaccine development.

In Japan alone, a vaccine for hepatitis non- $A$ non- $B$ is expected to have annual sales of $£ 4,000-5,000$ million $(\$ 30-35$ million), comparable to sales of the vaccine for hepatitis B which at present leads the vaccine market in Japan. There are also huge potential markets for a vaccine in other parts of Asia. Development of a vaccine is probably still several years away, according to one expert observer, but Chiron is getting closer to being the 'ultimate winner'.

David Swinbanks izes screening, traditionally gets test kits

\section{Students in US may be able to stay longer}

\section{Washington}

THE US Congress last week passed a bill that would allow Chinese students and scholars staying in the United States under temporary $\mathrm{J}-1$ visas to remain here after their visas expire. But the administration opposes the bill and the president may veto it before the deadline of 2 December.

The bill, sponsored by representative Nancy Pelosi (Democrat-California), is one of many introduced in July shortly after the Chinese People's Liberation Army shot unarmed protesters in Tiananmen Square but is the only one so far which is making any progress through Congress. It would waive the two-year residency requirement on $\mathrm{J}$ - 1 visas, held by most students and visiting scholars, which stipulates that the holder must return to the country of origin for two years before applying for another visa. The new rule would allow the holder to remain in the United States and apply for an extended temporary stay or permanent residence.

But in a statement released last week, the Department of State said it was strongly opposed to the bill on the grounds that it could damage academic exchanges between the two countries, which had been increasing until the government crackdown in June. If it becomes law it is "extremely unlikely" that the Fulbright exchange programme, which has been suspended since June, will be resumed and the impact on non-governmental exchange programmes might also be very severe, it said. The statement said that although the administration sympathizises with the reluctance of Chinese students to return now, it is is also concerned that their permanent loss to China might prevent future visits by others.

The bill has strong support in Congress, however. It was passed unanimously in the House of Representatives and with only a few dissenters in the Senate. A spokesman for Pelosi says that there is probably enough support to ensure that if President Bush vetoes the bill the veto will be overridden by a two-thirds majority in Congress. Christine McGourty

TECHNOLOGY TRANSFER

\section{Science park for Sri Lanka}

\section{Bangalore}

THE Arthur Clarke Centre for Modern Technologies will soon develop a 'technology park' designed to give industry in Sri Lanka better access to international technological expertise. The park will be located near the Katubedda University, Moratewa. Different groups in the park will be devoted to the design of new products, the analysis of industrial processes, and software development.

Radhakrishna Rao 